\title{
USE OF ELECTROSPRAY MASS SPECTROMTERY TO STUDY THE INTERACTIONS BETWEEN PARA-SULPHONATO-CALIX[4]ARENE AND A SERIES OF SERUM ALBUMIN PROTEINS
}

\author{
Jalil Moubarak, Elodie Moreno, Eric Diesis and Anthony W. Coleman* \\ Institut de Biologie et Chimie des Protéines, UMR 5086, CNRS, Université Lyon 1, 7 passage du Vercors, F69367 Lyon, France. \\ Tel +33 472722640; E-mail: aw.coleman@ibcp.fr

\begin{abstract}
The binding of para-Sulphonato-calix[4]arene to a series of Serum Albumin Proteins has been studied using Electrospray Mass Spectrometry, each protein shows different capacities to interact with para-Sulphonatocalix[4]arene, including the number of ligands bound, the Association Constants observed, and the stoichiometries at which the onset of each binding event is observed.
\end{abstract}

Keywords: Calix[n]arene, para-Sulphonato-calix[4]arene, Electrospray Mass Spectrometry, Binding Constants, Complex Stoichiometry, Sequential Binding

\section{Introduction}

The calix[n]arenes are amongst the most widely studied organic host molecules, [1] over the last ten years we and others have demonstrated that these synthetic macrocycles have a wide and highly interesting biology. [2] Studies on the interactions of the calix[n]arenes, and in particular the para-sulphonato-calix[n]arenes, with biomolecules have ranged from amino-acids, [3] nucleotides, [4] and steroids [5] through peptides [6] to various proteins, [7] and most recently to cellular biology [8] and in vivo-toxicity [9].

The calix[n]arenes have been shown to have direct biological properties including anti-coagulant, [10] antiviral, [11] anti-bacterial, [12] and anti-tumoral, [13] activities and also indirect activity where they have been used as colloidal transporters, [14] inclusion compounds for drug solubilisation, [15] protectant molecules against UV degradation, [16] co-crystal formers [17] and to be capable of acting as amplifying systems in neurodegenerative disease diagnostics. [18]

At this time the most studied and also the most versatile of the calix[n]arenes with regard to biological and bio-medical applications is para-sulphonato-calix[4]arene. It is usable as a co-crystal former, [17] as an inclusion compound solubilser [15] and for the formation of co-colloids for drug transport. [19] It has been shown to possess no hemolytic properties, [20] does not provoke non-specfic immune responses, [21] has no anticoagulant activity [10] and possesses very low in-vivo toxicity, [9] where in mice it is rapidly cleared from the body without accumulation. Thus para-sulphonato-calix[4]arene is an excellent candidate for use as a adjuvant for drug transport and delivery.

Of the circulating proteins, the Serum Albumins are the most important class with concentrations in physiological fluids of up to $40 \mathrm{~g} / \mathrm{L}$. [22] They are well known as anion transporter proteins and may thus act as reservoirs for delivery of negatively charged bioactive molecules. [22] Thus the study of the interaction of parasulphonato-calix[4]arene with various Serum Albumins is of considerable interest, in view of the possible medical applications of this molecule.

We have already reported on the interaction between para-sulphonato-calix[4]arene and Bovine Serum Albumin, (BSA), where three binding sites where observed with Association Constants of 0.77, 0.38 and $0.03 \times 10^{6} \mathrm{M}^{-1}$. [23]

Electrospray Mass Spectrometry has been widely developed for the study of the binding of small molecules to proteins, [24] the technique, which is a soft Mass Spectrometric method using low energy for ionisation, can provide information on both the stoichiometry and binding energies, [25] involved in supramolecular complexes and possesses high sensitivity. However, there exists still much discussion on the subject of whether the binding constants derived from ES-MS and the conformations of the proteins in the gas phase reflect conditions in the solution state. [26]

Given that the Serum Albumins are capable of adhering non-selectively to a wide range of surfaces, thus ruling out many analytical techniques such as SPR or HPLC and that they are not suitable for study by NMR due to their high molecular weight, over 65kD, the use of Electrospray Mass Spectromtery (ES-MS) is an excellent tool for the study of binding of ligands to the various Serum Albumins.

In the present work we have studied by ES-MS the interaction of para-sulphonato-calix[4]arene with Serum Albumins obtained from Human, (HAS), Goat, (GSA), Pork, (PSA), Rat, (RSA), Rabbit, (RbSA) and Sheep, (SSA). The use of a single substrate molecule with a closely related series of proteins under identical conditions should allow us to have some degree of confidence in the internal consistency of the results and permit quantitative comparisons to be undertaken. 


\section{Results and Discussion}

The synthesis of para-sulphonato-calix[4]arene, 1, below, was carried out using the conditions previously developed for samples to be used in biological studies. ${ }^{9}$

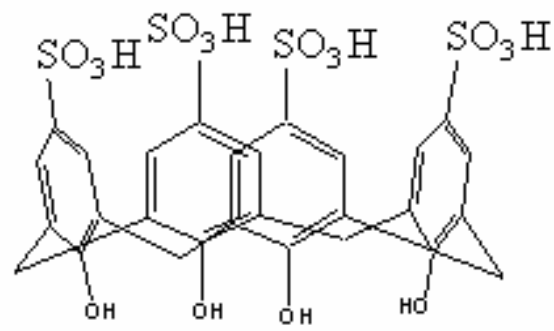

Scheme 1. Molecular Structure of para-sulphonato-calix[4]arene, 1.

A typical mass spectrum, at a 1:0.8 ration between para-sulphonato-calix[4]arene and Rat Serum Albumin, along with the deconvoluted spectrum are shown in Figure 1a and 1b respectively.

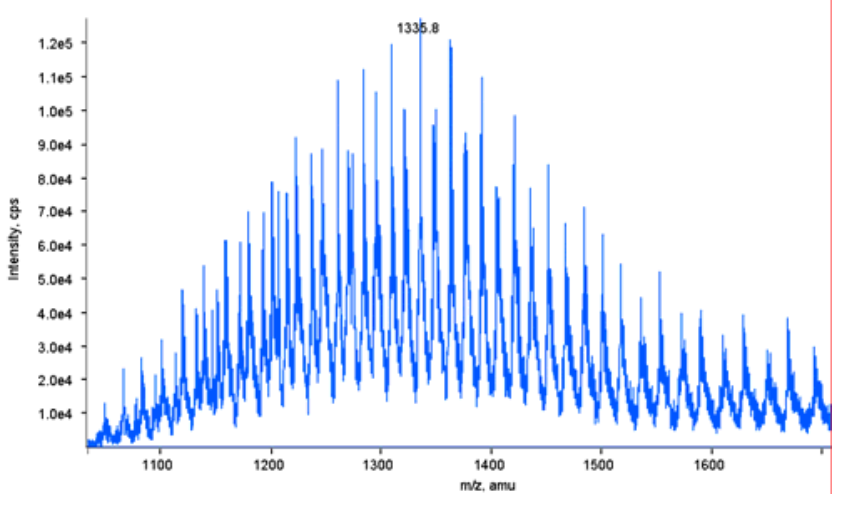

Figure 1a

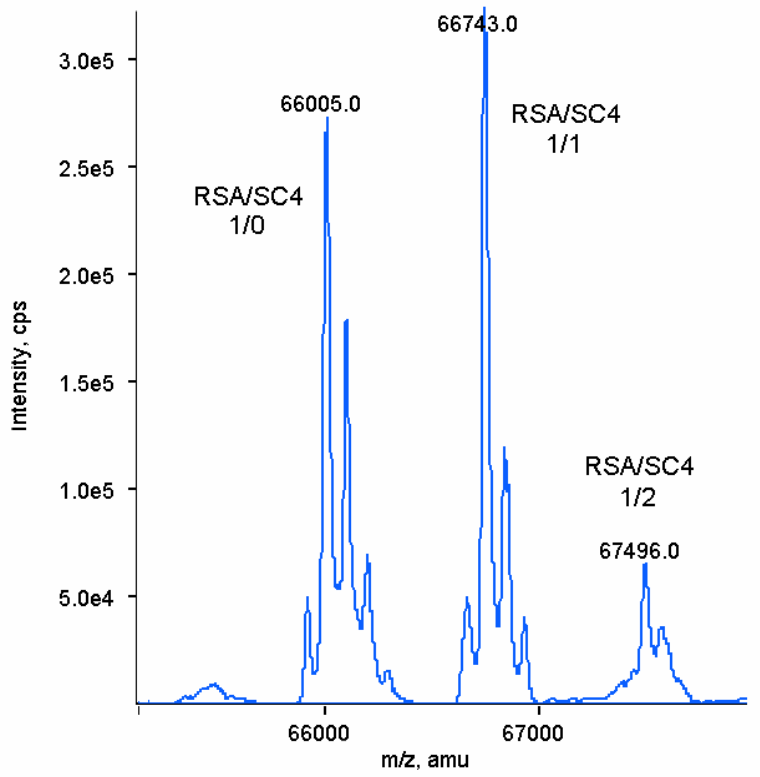

Figure 1b

Figure 1, a Native ES-MS spectrum of the complexation of Rat Serum Albumin by para-sulphonatocalix[4]arene, 1 at a molar ratio of $1: 0.8$, and $b$ the deconvoluted spectrum.

The high charge state naturally present on the Serum Albumins leads to median values for observed $\mathrm{m} / \mathrm{z}$ ratios in the range 1270 to 1390, as given in Table 1 . Also in Table 1 are given the number of basic amino-acids, Lysine, Arginine and Histidine present in each protein.

In Table 2 are given the data on the binding of para-sulphonato-calix[4]arene to each of the Serum Albumins, along with the Association Constants, $\mathrm{K}_{\text {ass, }}$ for each of the observed complexes.The Association Constants are expressed in $\mathrm{M}^{-1}$ as the mathematical treatment calculates each value as a separate entity.

Evidently a major point concerns the nature of the observed binding, is it specific or non-specific in nature. Given the high, between 90 and 100, number of basic amino acid residues present and that at most a 1:5 stoichiometry is observed, as well as the fact that for BSA up to 60 molecules of para-sulphonato-calix[4]arene are non-speficially coordinated to BSA, it would seem that under the experimental conditions used here, the binding can be treated as specific but not necessarily directly applicable to the in-vivo situation. In fact given the complexity of physiological media binding data obtained ex-vivo must, anyway, be treated with circumspection. 
Data for the various Serum Albumin Proteins, number of basic amino-acids present, median $\mathrm{m} / \mathrm{z}$ ratio observed. a Data for BSA from [23] b data unavailable

\begin{tabular}{l|lllllll}
\hline & $B A^{a}$ & $H S A$ & $G_{S A}{ }^{b}$ & $P S A$ & $R S A$ & $R b S A$ & $S S A$ \\
\hline Lys & 59 & 60 & $\mathbf{b}$ & 58 & 54 & 58 & 61 \\
Arg & 23 & 25 & $\mathbf{b}$ & 29 & 27 & 25 & 25 \\
His & 17 & 16 & $\mathbf{b}$ & 19 & 15 & 23 & 18 \\
$\begin{array}{l}\text { Median } \\
\text { m/z }\end{array}$ & & 1388 & 1386 & 1338 & 1335 & 1351 & 1280 \\
\hline
\end{tabular}

Table 2

Association Constants, observed for the complexes between para-sulphonato-calix[4]arene and the Serum Albumin proteins. ${ }^{\text {a }}$ Data for BSA from reference [23]

\begin{tabular}{c|ccccccc}
\hline & $B S A^{a}$ & $H S A$ & $G S A$ & $P S A$ & $R S A$ & $R b S A$ & SSA \\
& $10^{6} M^{-1}$ & $10^{6} M^{-1}$ & $10^{6} M^{-1}$ & $10^{6} M^{-1}$ & $10^{6} M^{-1}$ & $10^{6} M^{-1}$ & $10^{6} M^{-1}$ \\
\hline $1: 1$ & 0.77 & 2.13 & 0.84 & 0.52 & 1.52 & 1.66 & 0.16 \\
$1: 2$ & 0.38 & 1.06 & 1.25 & 0.45 & 0.91 & 1.72 & 1.06 \\
$1: 3$ & 0.03 & 0.31 & 0.27 & 0.14 & 0.30 & 0.49 & 0.68 \\
$1: 4$ & - & 0.11 & 0.08 & - & 0.10 & 0.16 & 0.17 \\
$1: 5$ & - & 0.03 & 0.03 & - & 0.03 & - & 0.06 \\
\hline
\end{tabular}

Analysis of the Association Constants shows that for all the Serum Albumins, except possibly PSA, there exist two very strong binding sites for para-sulphonato-calix[4]arene, with Kass values between $0.8 \times 10^{6} \mathrm{M}^{-1}$ and $2 \times 10^{6} \mathrm{M}^{-1}$ and that the sites are generally capable of accomodating two molecules of para-sulphonato-calix[4]arene.

There exists a second apparent type o fbinding site, as described by similarity in the observed Assocaition Constants with values grouped around $0.3-0.5 \times 10^{6} \mathrm{M}^{-1}$ and that this site only binds one molecule of para-sulphonatocalix[4]arene.

Finally two other types of site may exist, one showing Association Constants in the range $0.15 \times 10^{6} \mathrm{M}^{-1}$ to $0.1 \times 10^{6} \mathrm{M}^{-1}$ and the other around $0.03 \times 10^{6} \mathrm{M}^{-1}$. With regard to these last sites their presence is dependent on the animal source of the Serum Albumin.

Of further interest is the fact that there are apparently cooperative binding events in which the first Association Constant is smaller the second, this is particularly the case for Sheep Serum Albumin,(SSA) where for the first binding event a Association Constant of $0.16 \times 10^{6} \mathrm{M}^{-1}$ is observed, after which at higher molar ratios of parasulphonato-calix[4]arene to SSA by two strong binding events with Association Constants of $1.06 \times 10^{6} \mathrm{M}^{-1}$ and $0.68 \times 10^{6} \mathrm{M}^{-1}$ are observed before the second typical binding site at $0.17 \times 10^{6} \mathrm{M}^{-1}$ appears. These results suggest, that in the case of this protein, that complexation at an additional site opens up access for para-sulphonato-calix[4]arene to the strong double binding site.

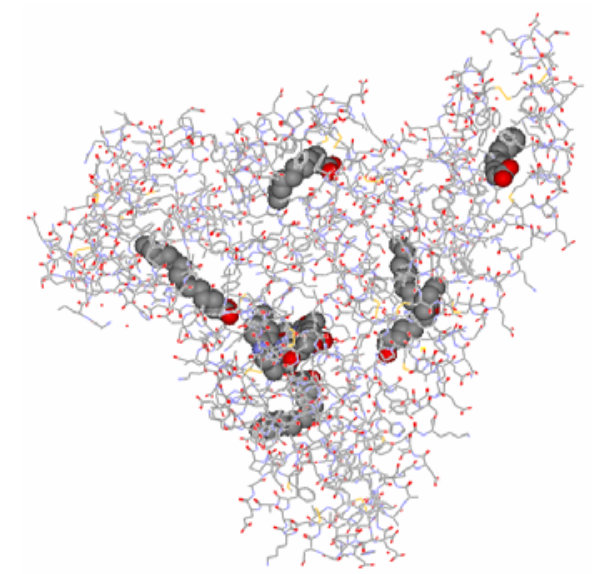

Figure 2, adapted from ref 27, molecular structure of HAS in its complex with myristate, azapropazone and indomethacin, showing the complexed molecules as CPK surfaces to better illustrate the possible binding sites.

The crystal structures of HSA, and more than twenty of its complexes with varying single molecules, and with two and even three different molecules are present in the Protein Data Bank.

Analysis of the binding sites present in the triple complex between HSA, myristate, azapropazone and indomethacin, [27], Figure 2 shows one large site that contains both azopropazone and indomethacin with two myristate anions close by, another quite large site with two myristate anions and two binding sites for one myristate each. 

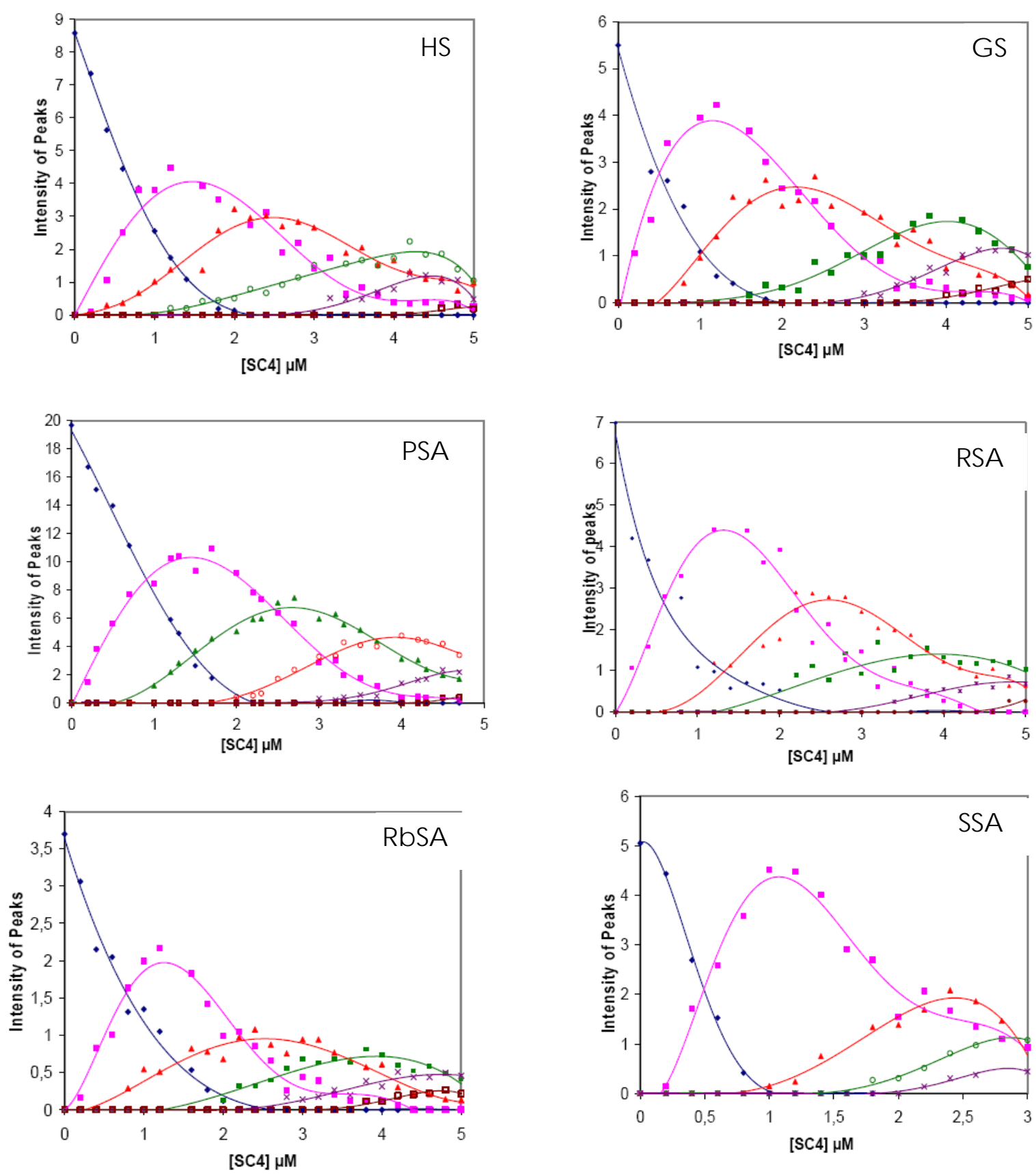

Figure 3. Titration curves for the complexation of para-sulphonato-calix[4]arene with the various Serum Albumins as a function of the concentration of para-sulphonato-calix[4]arene. Curve fitting has been applied to improve visualization, hence the initial value of the concentration of para-sulphonato-calix[4]arene becomes zero.

The observed sites could, thus, correspond to the two strong binding sites of para-sulphonato-calix[4]arenefor the large pocket, a second binding site and two weaker binding sites.

In addition to the thermodynamic information on individual binding events, ES-MS provides clear information on the onset of binding events and on the existance of the various binding events as a function of the stoichiometry of the titration, it is one very few analytical techniques that can provide such information. The curves for the variation of each complex are given in Figures 3a-f and the data is summarised in Table 3.

Interestingly for both GSA and, particularly, for RbSA there a lag before observation of the formation of the 1:1 complex, conversely only for HAS are the 1:1 and 2:1 complexes present at the initial extrapolated titration point. For all the other binding events there are sequential and there is never simultaneous formation of more than one stoichiometry. Interestingly for all the proteins other than PSA there is dissymmetry in the 1:1 binding curve with extension out to high para-sulphonato-calix[4]arene: protein ratios. 
Binding Event Onset Stoichiometry Ratios.

\begin{tabular}{c|cccccc}
\hline & $H S A$ & GSA & PSA & RSA & RbSA & SSA \\
\hline $1: 1$ & $>0$ & 0.03 & $>0$ & $>0$ & 0.16 & $>0$ \\
$1: 2$ & $>0$ & 0.46 & 0.5 & 0.51 & 0.72 & 0.15 \\
$1: 3$ & 0.69 & 0.82 & 1.63 & 1.22 & 1.29 & 1.22 \\
$1: 4$ & 2.54 & 2.45 & - & 2.58 & 1.8 & 2.11 \\
$1: 5$ & 3.88 & 3.24 & - & 4.22 & - & 3.14 \\
\hline
\end{tabular}

\section{Experimental}

\section{Sample preparation}

Serum albumins were purchased from Sigma and used without further purification. para-Sulfonatocalix[4]arenes was synthetised according to the literature method. [9] The mass spectra of solutions containing parasulfonatocalix[4]arene and the relevant Serum Albumins were carried out in a $\mathrm{CH}_{3} \mathrm{OH}-\mathrm{H}_{2} \mathrm{O}$ mixture (50:50; v/v) with $0.1 \%$ of Formic Acid. In the titration experiments, the final concentration of the Serum Albumins was retained constant at $5 \mathrm{pmol} / \mu \mathrm{L}$. Thus to $10 \mu \mathrm{L}$ of the Serum Albumin solutions was added increasing volumes of the relevant calixarene solution from 0 to $25 \mathrm{pm} / \mu$, the final volume was adjusted to $1 \mathrm{~mL}$. A mass spectrum of each sample was recorded. A minimun of 10 points was required to obtain the best fit for calculating the Association Constant value.

\section{ESI/MS mass spectra}

All experiments were performed using a Sciex API 165 quadrupole mass spectrometer, associated with an Electrospray Ionisation (ESI) source operating in the positive ion mode. Compounds were introduced by direct infusion of solutions at $5 \mu \mathrm{L} / \mathrm{min}$ flow rate in a $\mathrm{CH}_{3} \mathrm{OH} / \mathrm{H}_{2} \mathrm{O}(50: 50 ; \mathrm{v} / \mathrm{v})$ mixture containing $0.1 \%$ of $\mathrm{HCOOH}$. Mass spectra were acquired at $60 \mathrm{~V}$ orifice voltage value. The scan range was set at $\mathrm{m} / \mathrm{z} 700-2200$. Multicharged ion spectra were deconvolved in the 65 to $75 \mathrm{kDa}$ mass range with step-size of $0.1 \mathrm{Da}$ and 20 iterations were summed to improve the signal to noise ratio. Deconvolution of the raw mass spectra allows observation and subsequent integration of peaks arising from the serum albumin alone and peaks arising from the complexes. It is assumed that the ionisation response factors of the various Serum Albumins and the Serum Albumin-para-sulphonato-calix[4]arene complexes are the same.

Calculation of $K_{\text {Ass }}$

For the calculation of the $K_{D}$ values it is assumed that they are $n$ binding sites that are not necessarily equivalent, and where $\mathrm{K}_{\mathrm{D}}=$ Dissociation Constant:

$$
\begin{aligned}
K_{D 1} & =\frac{[P][C]}{[P C]} \\
K_{D 2} & =\frac{[P C][C]}{\left[P C_{2}\right]} \\
K_{D n} & =\frac{\left[P C_{n-1}\right][C]}{\left[P C_{n}\right]}
\end{aligned}
$$

where $\mathrm{P}$ is the free serum albumin concentration, $\mathrm{C}$ is the free para-sulphonato-calix[4]arene concentration, $\mathrm{PC}$ is the 1:1 Protein-para-sulphonato-calix[4]arene complex concentration, $\mathrm{PC}_{2}$ is the 1:2 Protein-para-sulphonatocalix[4]arene complex concentration and the equilibrium constants can also describe $n$ non equivalent binding sites:

$$
\begin{gathered}
K_{1}=\frac{[P][C]}{[P C]} \\
K_{2}=\frac{[P][C]^{2}}{\left[P C_{2}\right]}
\end{gathered}
$$

where $\mathrm{K}_{1}=\mathrm{K}_{\mathrm{D} 1}$ and $\mathrm{K}_{2}=\mathrm{K}_{\mathrm{D} 1} \times \mathrm{K}_{\mathrm{D} 2}$. Following the derivation in van Holde's Physical Biochemistry, [28] the relationship below is derived:

$$
\frac{[P]+[P C]+\left[P C_{2}\right]+\ldots+\left[P C_{n}\right]}{[P]}=\frac{[C]^{n}}{K_{D 1} K_{D 2} \ldots K_{D n}}+\ldots+\frac{[C]^{2}}{K_{D 1} K_{D 2}}+\frac{[C]}{K_{D 1}}+1
$$

The intercept will be one for a para-sulphonato-calix[4]arene concentration of zero. A plot of measured values of $\left([\mathrm{P}]+[\mathrm{PC}]+\left[\mathrm{PC}_{2}\right]+\ldots+\left[\mathrm{PC}_{n}\right]\right) /[\mathrm{P}]$ versus added $[\mathrm{C}]$ can be fitted to a $n$ order polynomial fonction, thus allowing calculation of each Dissociation Constant.

For calculating the association constant, it was assumed that the total signal response for each individual species was proportional to the concentration of that species both in the gas phase and in solution.

$\mathrm{K}_{\mathrm{ass}}$ is simply $1 / \mathrm{K}_{\mathrm{D}}$ 


\section{Conclusion}

The use of Electrospray Mass Spectrometry has allowed the investigation of the binding of para-sulfonatocalix[4]arene to a series of Serum Albumin Proteins. There are, depending on the protein, at least three and up to five binding sites observed, with the derived Association Constants varying from 2.14 to $0.03 \times 10^{6} \mathrm{M}^{-1}$. Comparison with the crystal structure of a Human Serum Albumin complex suggests that the binding of para-sulfonato-calix[4]arene may be correlated with the known anion binding sites. The onset of the formation of each complex is, in general, an independent event particular to the nature of the Serum Albumin.

\section{References}

[1]. C. D. Gutsche, An Introduction to the Calix-Arenes, Royal Society of Chemistry, Cambridge, 2008.

[2]. F. Perret, A. N. Lazar and A. W. Coleman, Chem. Commun., 2006, 2425 - 2438. E. Da Silva, A. N. Lazar and A. W. Coleman, Journal of Drug Delivery Science and Technology, 14, 2004, 3-20.

[3]. O. I. Kalchenko, F. Perret, N. Morel-Desrosiers and A. W. Coleman, Journal of the Chemical Society, Perkin Transactions 2, 2001, 258-263. N. Douteau-Guevel, A. W. Coleman, J.-P. Morel and N. Morel-Desrosiers, Physical Organic Chemistry, Perkin Transactions 2, Journal of the Chemical Society, 1999, 629-634. N. Douteau-Guevel, A. W. Coleman, J.-P. Morel and N. Morel-Desrosiers, Journal of Physical Organic Chemistry, 11, 1998, 693-696. O. I. Kalchenko, E. Da Silva and A. W. Coleman, Journal of Inclusion Phenomena and Macrocyclic Chemistry, 43, 2002, 305-310.

[4]. G. M. L. Consoli, G. Granata, E. Galante, I. Di Silvestro, L. Salafia and C. Geraci, Tetrahedron 63, 2007, 10758-10763.

[5]. E. Da Silva, C. Valmalle, M. Becchi, C.-Y. Cuilleron and A. W. Coleman, Journal of Inclusion Phenomena and Macrocyclic Chemistry, 46, 2003, 65-69.

[6]. N. Douteau-Guevel, F. Perret, A. W. Coleman, J.-P. Morel and N. Morel-Desrosiers, Journal of the Chemical Society, Perkin Transactions 2, 2002, 524-532.

[7]. F. Perret, H. Peron, M. Dupin and A. W. Coleman, in Topics in Current Chem, Creative Chemical Sensor Systems, ed T. Schrader, 277, 2007, 31-88, Springer, Berlin. T. Oshima, Y. Baba, K. Shimojo and M. Goto, Current Drug Discovery Technologies, 4, 2007, 220-228.

[8]. R. Lalor, H. Baillie-Johnson, C Redshaw, S. E. Matthews and A. Mueller, J. Am. Chem. Soc., 130, 2008, 2892-2893. R. Lalor, J. L. Di Gesso, A. Mueller and S. E. Matthews, Chem. Commun., 2007, 4907-4909. M. A. Klyachina,V. I. Boyko, A. V. Yakovenko, L. G. Babich, S. G. Shlykov, S. O. Kosterin, V. P. Khilya, V. I. Kalchenko, J. Incl. Phen. Macro. Chem., 60, 2008, 131-137.

[9]. A. W. Coleman, S. Jebors, S. Cecillon, P. Perret, D. Garin, D. Marti-Battle and M. Moulin, New J Chem, 32, 2008, 780-782.

[10]. E. Da Silva, D. Ficheux and A. W. Coleman J.Incl. Phen. Macro. Chem., 52, 2005, 201-6.

[11]. K. M. Hwang, Y. M. Qi, S. L. Liu and W. Choy, J. Chen, Treatment of infection by enveloped virus with calix[n]arene compounds, U.S. Patent , 1995, US 5,312,837.

[12]. P. D'Arcy Hart, J. A. Armstrong and E. Brodaty, Infection and Immunity 1996, 64, 1491-3. J. W. Cornforth, P. D'Arcy Hart, G. A. Nicholls, R. J. W. Rees, J. A. Stock, British Journal of Pharmacology and Chemotherapy, 10, 1955, 73-86.

[13]. A. W. Coleman, A. N. Lazar, L. G. Bagetto, S. Magnard and M. H. Michaud, Dérivés de Calixarènes comme Agents Anticancéreux, 2007 International Patent, PCT/FR2007/051127. C. Geraci, G. M. L. Consoli, E. Galante, E. Bousquet, M. Pappalardo and A. Spadaro, Biocon. Chem., 19, 2008, 751-758.

[14]. P. Shahgaldian, E. Da Silva, A. W. Coleman, B. Rather and M. J. Zaworotko, International Journal of Pharmaceutics, 253, 2003, 23-38.

[15]. W. Yang, M. M. de Villiers, 7, AAPS Journal, 2005, E241-E248.

[16]. M. Pojarova, G. S. Ananchenko, K. A. Udachin, M. Daroszewska, F. Perret, A. W. Coleman and J. A. Ripmeester, Chem Mat, 18, 2006, 5817-5819.

[17]. N. Dupont, A. N. Lazar, F. Perret, O. Danylyuk, K. Suwinska, A. Navaza and A. W. Coleman, CrystEngComm, 2008, *DOI:* 10.1039/b805317k.

[18]. A. W. Coleman, F. Perret, S. Cecillon, A. Moussa, A. Martin, M. Dupin and H. Perron, New J. Chem., 31, 2007, 711-717.

[19]. A. W. Coleman, A. N. Lazar and J.-Y. Renault, Co-colloïdes supramoléculaires obtenus à l'aide de systèmes macrocycliques polyanioniques, French Patent FR 2904782, 2006.

[20]. E. Da Silva, P. Shahgaldian and A. W. Coleman, Int. J. Pharm., 273, 2004, 57-62.

[21]. M.-H. Paclet, C. F. Rousseau, C. Yannick, F. Morel and A. W. Coleman, J.Incl. Phen. Macro. Chem., 55, 2006, 353-8.

[22]. T. Peters Jr, All About Albumin, Academic Press, San Diego, 1995.

[23]. E. Da Silva, C. F. Rousseau, I. Zanella-Cleon, M. Becchi and A. W. Coleman, J.Incl. Phen. Macro. Chem., 55, 2006, 53-9.

[24]. A. J. R. Heck and R.H.H. van den Heuvel, Mass Spectrom. Revs, 23, 2004, 368- 389.

[25]. J. M. Daniel, S. D. Friess, S. Rajagopalan, S. Wendt and R. Zenobi, Int. J. Mass Spectrometry, 216, 2002, 1-27.

[26]. M. C. Jecklin, D. Touboul, C. Bovet, A. Wortmann and R. Zenobi, J. Am. Mass Spectrom, 19, 2008, 323-43.

[27]. J. Ghuman, P. A. Zunszain, I. Petitpas, A. A. Bhattacharya, M. Otagiri, and S. Curry, J. Mol. Biol., 353, 2005, 38-43.

[28]. K. E. Van Holde, Physical Biochemistry, $2^{\text {end }}$ ed., Prentice-Hall, Englewood Cliffs, New Jersey, 1985. 